\title{
PPP in action
}

\section{Insights from primary EFL lessons in Vietnam}

\author{
Trang Le Diem Bui and Jonathan Newton \\ An Giang University | Victoria University of Wellington
}

The presentation-practice-production (PPP) approach is used in primary schools in Vietnam to teach speaking skills. However, there is disagreement about the theoretical validity and practical efficacy of PPP (Ellis, 2018; Willis \& Willis, 2007) and little research evidence for how teachers actually implement PPP and their views of this approach. The current study addresses this gap. Seven teachers from six primary schools in Vietnam were observed teaching 11 PPP speaking lessons and were then interviewed on their experience of teaching the lessons. Analysis of the observation data showed that all seven teachers followed all three phases of the PPP sequence in their lessons. However, they frequently added interactive activities to the presentation phase and adapted production activities to make them more communicative. The teachers held mixed views of PPP: Three spoke positively of its value for lower level classes, another teacher was somewhat neutral while the remaining three teachers were dismissive of it and actively sought to adopt a more communicative approach. Overall, findings from the study reveal limitations of the PPP approach as it is practiced in this context and highlight affordances for making PPP more communicative, including drawing on principles of effective task design.

Keywords: presentation-practice-production (PPP), textbooks, speaking lessons, primary schools, task-based language teaching (TBLT), Vietnam

\section{Introduction}

The presentation-practice-production (PPP) approach emerged in the 1970s as part of a trend towards more communicative approaches to English language teaching (Harmer, 2007). PPP seeks to build communicative abilities through carefully sequenced explicit teaching of target structures (Presentation) followed by controlled practice (Practice) and then by communicative use (Production). PPP has remained popular in textbook materials and teacher training programs 
(Anderson, 2017); however, as discussed below, its efficacy has been challenged (e.g. Ellis, 2018; Willis \& Willis, 2007). Classroom-based research has mainly evaluated the efficacy of the PPP approach in comparison with alternative approaches such as task-based language teaching (TBLT) (e.g. Carless, 2009; V.G. Nguyen, 2014) or through investigations into teacher education (e.g. Choi \& Andon, 2014) or education policy (e.g. H.M. Nguyen, 2011). Little research has accounted for how teachers implement PPP and how they perceive the efficacy of the approach. The current study addresses this gap by investigating how seven teachers in six primary schools in Vietnam implemented textbook PPP speaking lessons. In doing so, it seeks to provide insights into PPP as it is actually practised in authentic classrooms and thus to contribute to the growing body of research into teaching English to young learners (TEYLs) (e.g. Butler, 2015; García Mayo, 2018; Pinter, 2017).

\section{Literature review}

\subsection{The PPP approach}

The PPP approach was developed by British scholars at the dawn of CLT (Anderson, 2017). In PPP, individual language items are first explicitly presented $\left(\mathrm{P}_{1}\right)$, then practiced $\left(\mathrm{P}_{2}\right)$ in isolated sentences through controlled activities, and finally, learners produce $\left(\mathrm{P}_{3}\right)$ the target language items in a freer manner (Harmer, 2007). According to Anderson (2017), the main innovation in PPP was that it added the production phase to the earlier Situational Language Teaching (the Oral Approach) to address a concern that learners had too few opportunities for communicative practice. As Byrne (1986, p.2, original italics) argued, "no real learning can be assumed to have taken place until the students are able to use the language for themselves". Reflecting this view, communicative activities such as role-plays, discussion and language games became increasingly popular in teaching materials and PPP grew in popularity (Anderson, 2017).

From a theoretical perspective, PPP finds support in skill acquisition theory (SAT) which claims that learning starts with explicit attention to a linguistic feature to establish declarative knowledge which is then proceduralized and automatized through practice. DeKeyser $(2007,2017)$ distinguishes two forms of practice needed to first proceduralize and then automatize declarative knowledge. The first of these, communicative drills, involve learners exchanging information in carefully structured activities so as to develop procedural knowledge. But as DeKeyser (2007) points out, communicative drills in the practice phase ( $\left.\mathrm{P}_{2}\right)$ are often replaced with monotonous and repetitive mechanical drills that are 
unlikely to engage learners in "the essence of language processing, i.e., establishing form-meaning connections" (DeKeyser, 2007, p.11). Dörnyei’s (2013) principled communicative approach also stresses that drills should be motivating and related to some communicative function. The second form of practice described by DeKeyser is open-ended, meaning-focused activities. As utilized in the Production phase $\left(\mathrm{P}_{3}\right)$, these activities help learners to further proceduralize and automatize the form-meaning connections established in the earlier phases.

PPP finds support from research on explicit form-focused instruction. Both Anderson (2017) and DeKeyser (2017) argue that the meta-analyses on the effectiveness of L2 instruction by Norris and Ortega (2000) and Spada and Tomita (2010) provide support for the kind of explicit instruction on which PPP is based. However, Ellis (2018) cautions that these studies measured the effectiveness of instruction using tests of explicit language knowledge and so did not measure learning in terms of learners' ability to produce the targeted structures in spontaneous language use. DeKeyser (2017, p. 22) also acknowledges that this body of research "says very little about skill acquisition" because little is known about whether or how learners in these studies acquired declarative, proceduralized and automatized knowledge.

Researchers and practitioners who favor a more implicit, meaning-focused approach to language teaching have challenged PPP and the assumptions on which it is based (e.g. Ellis \& Shintani, 2014; Long, 2015; Skehan, 1996; Willis \& Willis, 2007), namely that it views language learning as linear and takes no account of the gradual and organic nature of language learning. These scholars argue that, contrary to PPP, language learning is driven primarily by communicative needs and opportunities to engage in purposeful language use rather than by explicit instruction and repetitive practice. Such claims find expression in TBLT in which purposeful tasks and not language forms are the focal unit of instruction; it is the task that draws the learner's attention to the language forms needed to understand or express the meanings needed to complete the task.

It is clear that PPP and TBLT take contrasting routes to achieve the goals of CLT. But while TBLT has stronger theoretical support (e.g. Ellis, 2018; Long, 2015), the clear structure of PPP and its proximity to more traditional teaching approaches have ensured its continued popularity, especially in English as a foreign language (EFL) contexts (Anderson, 2017).

\subsection{Classroom implementation of PPP}

Research on how teachers actually implement PPP in practice remains limited. Studies on this topic typically report on the challenges involved in shifting teachers from PPP to more communicative approaches such as TBLT. For example, 
Carless (2009) interviewed 12 Hong Kong secondary school teachers and 10 teacher educators to examine their views of TBLT and PPP subsequent to the introduction of TBLT into this school system. Half of the teachers expressed a preference for PPP. They perceived it to be more effective in facilitating grammar instruction and in providing them with a clear instructional role. In contrast, the majority of teacher educators (8/10) preferred TBLT to PPP. They commented that PPP resulted in lack of student engagement and interest in contrast to taskbased learning which they saw more enjoyable for students. The teachers also reported that their students found TBLT more enjoyable, even if they themselves preferred PPP.

V.G. Nguyen (2014) investigated Vietnamese high school teachers' practices and perceptions regarding forms-focused and meaning-focused approaches. He found that, like the teachers in the Carless study, these teachers preferred using forms-focused instruction and found it difficult to switch to a more meaningfocused, task-based approach. They believed that their students needed to understand grammatical features before they could communicate effectively. Not surprisingly, these teachers only taught the first two PP phases due to lack of time and expertise to implement the third communicative phase. Interestingly, this attachment to traditional form-focused teaching persisted despite the textbook claiming itself to be task-based.

In the broader context of investigating primary English education policy in Vietnam, H.M. Nguyen (2011) examined the methods used to teach English at a private and a public school. Observation data revealed that while teachers in the public school followed the PPP model, those in the private school used a wider variety of communicative activities, allowing more opportunities for authentic communication in English. The public school teachers reported that limited class time and large class size prevented them from using a more communicative approach. The author concluded from her classroom observations that the PPP approach the teachers used was ineffective for promoting communicative language use. Similarly, and also in the Vietnamese context, V.G. Nguyen, Le, \& Barnard (2015) report on teachers' resistance to adopting more communicative teaching methods.

Choi and Andon (2014) investigated the impact of an innovative teacher certification scheme on English teaching practices in South Korea. The program involved training teachers to adopt PPP, which in this context was seen as a "pragmatically feasible" (p.15) step towards more communicatively oriented teaching. Four case teachers were assessed on their ability to conduct PPP lessons in primary and secondary schools. Each of the four case teachers was observed teaching a regular lesson for assessment and took part in a post-lesson interview. Two teachers who passed the assessment were able to carry out activities that led stu- 
dents to communicate in English, while the other two unsuccessful teachers carried out only individual, non-communicative activities. At the conclusion of the program, three of these teachers stated that they would not adopt PPP in their future lessons due to its irrelevance to their teaching contexts.

With the exception of this last study, research into classroom implementation of PPP has mainly done so in relation to the introduction of TBLT. The teachers in these studies have, with a few exceptions, shown a preference for PPP over TBLT. However, little research has provided a comprehensive account of PPP as it is actually practiced in authentic classrooms. The current study seeks to address this gap through investigating the ways in which primary school EFL teachers in Vietnam implemented PPP lessons and how they explained their implementation decisions.

\section{Methodology}

This study adopted a multiple case study approach to research design, an approach which has been widely used in research into teacher cognition (e.g. Borg, 2006) and which allows for detailed, in-depth understanding of what is being studied (Stake, 1995). An interpretive research paradigm was also employed because its goal is to "understand the inner perspectives and meanings of actions and events of those being studied" (Anderson \& Burns, 1989, p. 67). The research addressed the following research questions (RQ):

1. a. What implementation decisions did the teachers make when teaching PPP speaking lessons?

b. How did they explain their implementation decisions?

2. What beliefs did the teachers hold regarding the value of the PPP approach?

\subsection{The context}

This study took place in six primary schools across a Mekong Delta province in the South of Vietnam from August to November 2015. The schools had been selected to implement a new CLT-based primary English curriculum issued in 2010 because they had sufficient facilities (i.e. classroom spaces) and enough qualified teachers who had obtained a B2 or above CEFR certificate. The curriculum made English a compulsory subject, starting from Grade 3 (age 9) and increased English lessons from two to four lessons per week. Teachers were required to assess learning in terms of learners' ability to communicate in English with a particular focus on the listening and speaking skills. Assessment included continuous 
in-class assessment and end-of-term written and oral exams. The curriculum is linked to the 2008-2020 National Foreign Languages Project (NFLP), which was introduced to improve the English proficiency of primary school students so that they can obtain a foundation Level A1 in the Common European Framework of Reference (CEFR) at the end of primary school.

Accompanying the new curriculum is a new textbook series Tieng Anh 3-4-5 (Hoang et al., 2015) for Grades 3, 4 and 5, ${ }^{1}$ which was introduced in 2013. This series is reported to "succeed quite well in adopting a communicative language teaching approach" (Dang \& Seals, 2018, p. 108). The textbooks contain 20 units on topics such as Me and my friends, Me and my School, and Me and my family. Each unit consists of three 'lessons' with each lesson made up of five or six activities. In practice, however, the teachers divided each textbook lesson into two lessons taught across two separate periods, making six classroom lessons for each unit. Of these six, two were PPP speaking lessons and these lessons introduced the target structures for the unit. These structures were practiced in follow-up skillintegrated activities such as Read and write, Listen and write, and "Project" work.

\subsection{Teacher participants}

The participants were seven primary English teachers working in six public primary schools in rural, semi-rural and urban settings. They were selected through a two-stage criterion sampling process (Dörnyei, 2007). First, a pool of 18 qualified English teachers at B2 level of CEFR or above who worked at schools proximate to the researcher's location were identified. All teachers except one were not known to the researchers. Second, the pool of potential participants was narrowed to those who had used the textbooks for at least two years and had received one-off training workshops provided by textbook writers. Because data collection was conducted only three years after the introduction of the textbooks in 2013, only eight teachers met these criteria, seven of whom accepted an invitation to participate in the research. This sampling process was not intended to achieve representativeness of primary school EFL teachers in Vietnam, but of teachers who were qualified implementers of the new curriculum. Details of the seven participating teachers are provided in Table 1 . Their age ranged from 24-36 and they had between three and thirteen years of teaching experience. Four of the teachers taught four Grade 4 classes and three taught Grade 3, with two each from urban and semi-rural schools and three from rural schools. These teachers taught English only.

1. Grade 5 textbooks were still being revised at the time of the study. 
Table 1. Details of the participant teachers

\begin{tabular}{lcclllc}
\hline $\begin{array}{l}\text { Teachers } \\
\text { (pseudonyms) }\end{array}$ & $\begin{array}{c}\text { Age } \\
\text { (years) }\end{array}$ & $\begin{array}{c}\text { Experience } \\
\text { (years) }\end{array}$ & Qualifications & Gender & $\begin{array}{l}\text { school } \\
\text { setting }\end{array}$ & Grade \\
\hline Lan & 24 & 3 & BA & F & Urban & 4 \\
Nga & 26 & 4 & BA & F & Urban & 3 \\
Nhu & 35 & 12 & BA & F & Semi-rural & 4 \\
Ly & 36 & 13 & BA & F & Semi-rural & 3 \\
Hoa & 26 & 5 & BA & F & Rural & 4 \\
Mai & 26 & 5 & BA & F & Rural & 3 \\
Nam & 26 & 5 & BA & M & Rural & 4 \\
\hline
\end{tabular}

Note. $\mathrm{F}=$ Female, $\mathrm{M}=$ Male, $\mathrm{BA}=$ Bachelor of Art

\subsection{Data collection and analysis}

The seven teachers were observed over a three-month period. The four Grade 4 teachers were observed teaching two speaking lessons (40 minutes each) and the Grade 3 teachers one speaking lesson ( 35 minutes each). These eleven speaking lessons were video-recorded and field notes taken by the researcher. The notes included a detailed description of what happened in all stages of each lesson with particular attention to activities which were added or adapted and students' reactions to these activities. Shortly after each observed lesson (either the same day or the following day), stimulated recall interviews (SRIs) were carried out following guidelines suggested by Borg (2006) and Gass and Mackey (2000). In the SRIs, the teachers were provided with samples of recordings from the previous lesson or a description of part of the lesson and asked to comment about their decision making and thinking processes related to this material. Two or three days after the SRIs, a follow-up in-depth interview was carried out with each teacher to explore more deeply the teachers' views on teaching PPP lessons. In the final part of the interviews the teachers were also introduced to TBLT. The researcher outlined orally a number of core principles of TBLT drawn from Ellis (2003) and Willis and Willis (2007) and illustrated these principles with examples of tasks. Their responses to this material were included in the data set as reported below. A total of 6.5 hours of interview data were analyzed.

Analysis started with the 11 recorded speaking lessons. The researcher watched each lesson repeatedly and made notes on emerging issues related to activities added or adapted and students' reactions to the activities. These notes were then checked against field notes. Transcription was restricted to classroom episodes that illustrated typical ways of implementing key stages in the lessons. 
Coding of the observation data was carried out manually using Microsoft Excel spreadsheets. Patterns and themes were identified using the "constant comparative method" (Merriam \& Tisdell, 2016, p. 208) based on detailed written descriptions of all lessons and involving an iterative, cyclical and inductive analytic process (Dörnyei, 2007).

All interviews were conducted in Vietnamese and translated into English by the researcher. A Vietnamese EFL university teacher checked the translations. The interview data were analysed manually following an inductive approach to data analysis (Dörnyei, 2007). This approach allowed common themes to be identified through an iterative process of reading and coding the transcripts.

A study of this kind faces the observer's paradox (Labov, 1972) in that the act of being observed may change the behaviour which is being observed. This potential threat to the validity of the research was addressed in three ways. First, it was made clear to the teachers and their pupils that their performance was not being assessed. Second, all teachers understood that their typical classroom practices and authentic and honest responses were important for the integrity of the study. Third, and of particular importance in this context, the teachers were all accustomed to being regularly observed by colleagues or inspectors since this is a routine part of teaching in the public school sector in Vietnam. We also sought to mitigate the presence of a video camera by placing the camera unobtrusively at the back of the classroom and by recording lessons in each classroom prior to those used in the research in order to normalize the presence of the camera.

\section{Results}

In this section, results are reported on how the teachers implemented each of the PPP phases, their stated rationales for their implementation decisions (RQs 1a and $1 b$ ) and their overall views on the PPP approach (RQ 2).

\subsection{Teachers' PPP practices and the rationales of their implementation decisions}

Observation data from the PPP speaking lessons show that all seven teachers followed the PPP sequence as instructed in the Teacher's Book. Not only did they carry out all three phases of the PPP speaking lessons, but they also frequently added interactive game-like activities to the presentation phase and replaced the textbook production activities with more communicative and task-like activities. Table 2 presents the procedures used by the teachers to implement each of the phases of the speaking lessons and whether each activity was present or absent. 
Table 2. The procedure the teachers employed to implement the PPP speaking lessons

\begin{tabular}{|c|c|c|c|c|c|c|c|c|}
\hline \multirow{3}{*}{$\begin{array}{c}\text { PPP speaking } \\
\text { lessons }\end{array}$} & \multicolumn{3}{|c|}{$\begin{array}{l}\text { Grade } 4 \text { teachers } \\
\qquad(n=4)\end{array}$} & \multicolumn{5}{|c|}{$\begin{array}{c}\text { Grade } 3 \text { teachers } \\
\qquad(n=3)\end{array}$} \\
\hline & Nhu & Hoa & Nam & & & Mai & Ly & Nga \\
\hline & $\mathrm{L}_{1} \quad \mathrm{~L}_{2}$ & $\mathrm{~L}_{2}$ & $\mathrm{~L}_{1}$ & $\mathrm{~L}_{1}$ & $\mathrm{~L}_{2}$ & $\mathrm{~L}_{2}$ & L2 & L2 \\
\hline
\end{tabular}

Presentation

a. Warm-up activities to review vocabulary

b. Pre-teach the new vocabulary

c. Vocabulary practice activities

d. Listen to the recording of the dialogues

e. Drill-based dialogue practice f. Explicit explanations of target structures

Time spent

(minutes)

\section{Practice}

g. Substitution drills of target structural patterns

h. Pair work practice and performance.

Time spent (minutes)

Production

i1. Use freer practice activities specified in the textbook. 
Table 2. (continued)

\begin{tabular}{|c|c|c|c|c|c|c|c|c|c|c|c|}
\hline \multirow{3}{*}{$\begin{array}{l}\text { PPP speaking } \\
\text { lessons }\end{array}$} & \multicolumn{6}{|c|}{$\begin{array}{c}\text { Grade } 4 \text { teachers } \\
\qquad(n=4)\end{array}$} & \multicolumn{5}{|c|}{$\begin{array}{c}\text { Grade } 3 \text { teachers } \\
\qquad(n=3)\end{array}$} \\
\hline & \multicolumn{2}{|c|}{ Nhu } & \multicolumn{2}{|c|}{ Hoa } & \multicolumn{2}{|c|}{ Nam } & \multicolumn{2}{|c|}{ Lan } & \multirow{2}{*}{$\frac{\text { Mai }}{\mathrm{L}_{2}}$} & \multirow{2}{*}{$\begin{array}{l}\text { Ly } \\
\text { L2 }\end{array}$} & \multirow{2}{*}{$\frac{\mathrm{Nga}}{\mathrm{L}_{2}}$} \\
\hline & $\mathrm{L}_{1}$ & L2 & $\mathrm{L}_{1}$ & $\mathrm{~L}_{2}$ & L1 & $\mathrm{L}_{2}$ & $\mathrm{~L}_{1}$ & $\mathrm{~L}_{2}$ & & & \\
\hline $\begin{array}{l}\text { i2. Replace the } \\
\text { production } \\
\text { activities with } \\
\text { game-based } \\
\text { practice activities }\end{array}$ & $\sqrt{ }$ & & & $\sqrt{ }$ & $\sqrt{ }$ & & & & $\sqrt{ }$ & & \\
\hline $\begin{array}{l}\text { i3. Replace the } \\
\text { production } \\
\text { activities with } \\
\text { communicative } \\
\text { tasks }\end{array}$ & & $\sqrt{ }$ & $\sqrt{ }$ & & & $\sqrt{ }$ & & & & $\sqrt{ }$ & $\sqrt{ }$ \\
\hline $\begin{array}{l}\text { Time spent } \\
\text { (minutes) }\end{array}$ & 10 & 9 & 10 & 9 & 4.2 & 9 & 4 & 4 & 2.5 & 6 & 6 \\
\hline $\begin{array}{l}\text { Consolidation } \\
\text { (minutes) }\end{array}$ & 2 & 3 & - & 2.5 & 4 & 2 & 1 & 1 & 3 & 3 & 2 \\
\hline $\begin{array}{l}\text { Total time } \\
\text { (minutes) }\end{array}$ & 41 & 40.5 & 40 & 39 & $37 \cdot 3$ & 43 & 42.4 & 42 & 34.5 & 34.5 & 35 \\
\hline
\end{tabular}

Note. $\mathrm{L}_{1}=$ speaking lesson $1 ; \mathrm{L} 2=$ speaking lesson 2

\subsubsection{Presentation}

Three common patterns emerged from analysis of the procedures the teachers used to implement the presentation phase. First, all seven teachers preceded the presentation phrase with a vocabulary activity and then a listening activity. The vocabulary activities included review activities such as "sing a song", pre-teaching activities such as "mind-map", 2 and practice activities such as "slap the board" (see rows (a), (b) and (c) in Table 2). The teachers' explanations for adding these activities reveal three common goals: creating an initial enjoyable classroom atmosphere, pre-teaching new vocabulary items, and memorising target vocabulary.

2. In the "mind-map" activity, students were required to visually organize vocabulary on the board relevant to the topic of the lesson, which had been elicited by the teacher.

3. The "slap the board" activity involved students running to the board and slapping the right word shouted out by the teacher or a student. 
For all the teachers, the listening activity simply involved getting the students to listen to the recording of the relevant dialogue from the lesson three times. The presence of these listening activities is not typical of PPP but is consistent with recommendations from the TBLT literature that learners can benefit from listening to others performing an activity before doing it (Ellis, 2018; Willis \& Willis, 2007).

Second, as specified in the Teachers' book, all teachers conducted drill-based dialogue practice to deliver Section 1 ("Look, listen and repeat"). This activity follows three main steps: (1) getting the students to repeat the dialogues after the teacher, (2) dividing the role between the students and the teacher, and/or (3) getting pairs/groups of students to play the role of the people in the dialogues. Each teacher spent between five to seven minutes drilling the dialogues.

Third, the teachers all concluded with explicit explanation of the target structures such as "Where is your school? It is on..." in one of the Grade 4 lessons. In the SRIs, all teachers explained that drilling the set dialogue helped the students practice pronouncing and speaking English. They stated that repetitive practice helped their students remember the patterns better and prepared them well for the next activities. As Mai, a Grade 3 teacher, commented:

Repetitive practice helps the students remember the structures [...]. They cannot speak English if they do not remember the structural patterns.

(Mai, speaking lesson 2)

However, three of the Grade 4 teachers (Nam, Hoa and Nhu), while acknowledging the benefits of following the steps, cited some drawbacks. As Nam said:

The steps are very mechanical. Students listen and repeat the dialogues, but they do not understand much from such repetition. The repetition just helps them practice the vocabulary.

(Nam, speaking lesson 2)

While acknowledging the benefit of practicing words by repetition, Hoa did not think that such dialogue practice was useful for communication. As she said:

The steps are too mechanical and time-consuming [...]. Dialogue practice encourages learning from imitation. This fails to help real language use.

(Hoa, speaking lesson 1)

Following the drill-based dialogue practice, all teachers explained the form, meaning and use of the target structural pattern extracted from the dialogue. Excerpt 1 from one of Lan's lessons illustrates this point by showing how Lan provided declarative knowledge of the target structure (Lan was the only teacher to do this in English). 


\section{Extract 1.}

Target structure explanations (Lan, speaking lesson 1)

$01 \mathrm{~T}$ : Now you have read about this presentation, how to ask about the location of your school, the location of your school. How to ask, what question?

$02 \mathrm{~S}_{1}$ : [T calls one volunteer] Where is your school?

03 T: Where's your school? Very good! Okay. This is the grammar to learn today [T shows the question "Where is your school?" on the PPT slide] "Where's your school?" and you will answer by saying [T shows the answer form "It's in...." on the PPT slide)] ... it's in ..., it's in.... Okay? For example, our school, where is your school?

04 Ss: It's in Vo Thi Sau street.

05 T: Yeah. Very good. It's in Vo Thi Sau street. And so...what is the meaning of "Where is your school?" What is the meaning?

06 Ss: Trường bạn ở đâu? (Where is your school?)

$07 \mathrm{~T}$ : Very good. [T shows the meaning of the question in Vietnamese]. And the usage [T shows the explanation of the usage in English], we use this question to ask and answer about the location of school ...location [T writes on the board].

Where is your school?

It is in Vo Thi Sau street.

(Trường bạn ở đâu?)

Write down in your notebook. Two minutes please. Two minutes. Note. $\mathrm{T}=$ teacher; $\mathrm{S}=$ student; $\mathrm{S}$ = many students

Lan justified this practice in the following way:

It was important for the students to know the target structures because it would be difficult for the teacher to carry out the next speaking activities without showing the students the structural patterns that they should use.

(Lan, speaking lesson 1)

This view was shared by all seven teachers. However, as evidenced in this extract, student S1 may have already acquired the target structure thus highlighting a problem with PPP that little account is taken of whether students might already know the pre-determined target structure.

\subsubsection{Practice}

The practice phase involved carrying out Section 2, "Point and say". As specified in the Teacher's book, the activities for this phase were primarily designed for stu- 
dents to ask and answer in pairs using target question and answer patterns from the dialogues in Phase 1 . The teachers spent between seven to ten minutes conducting this practice activity through teacher-led drill practice and/or and pairwork practice. For example, Nhu conducted the ask-and-answer practice activity for the target pattern "What is the date today? It is...". Nhu first ran through the four pictures and word prompts provided for substitution. Then she conducted the teacher-led drill practice activity by having students do the choral and then the individual ask-and-answer activity repeatedly.

Again, although the teachers shared common ways of conducting the practice phase, their perspectives on the value of practice varied. Most of the teachers, notably Mai, Ly and Lan, highlighted the important role this phase played in preparing students for the production phase. They agreed that these mechanical drills, which involved choral and individual drilling, give their students a sense of security and confidence to move to the production phase. Mai, a Grade 3 teacher provided a typical comment:

Students need a lot of repetitive practice to master the new structural patterns. If this step is skipped, it would be difficult for them to proceed to the production phase.

(Mai, speaking lesson 2)

However, Nga, Nam, and Hoa, while acknowledging the preparatory role of the practice phase, noted the mechanical and decontextualized features of the drill practice activity. For example, in talking about the practice phase in the interview, Nga provided an example from her lesson which asked her students to practice the pattern "Are they your friends?" Yes, they are / No, they aren't". In the textbook, there are four pictures of textbook characters. Pairs of students are required to answer "Yes" to the first two pictures and then "No" to the second two pictures, although none of the characters in the four pictures are their real friends. Nga, a Grade 3 teacher, had this to say on this activity:

I feel that my students cannot learn much from this pair work practice. They have to keep in mind that they have to say "Yes" when they are asked about the first two pictures and then say "No" when they are asked about the next two pictures. The questions initiate meaningless answers. This practice is mechanical and unreal.

(Nga, speaking lesson 2)

Nga's comment supports DeKeyser's (2007) criticism of mechanical drills from a skill acquisition perspective.

\subsubsection{Production}

Analysis of the classroom observation data indicates that the production stage was highly engaging. Most teachers used English to give instructions for the produc- 
tion activities, but some translated them into Vietnamese to aid understanding. In only two of the eleven lessons were the production activities carried out as specified in the textbook. Both were activities in which students exchanged personal or real information in pairs or groups and then performed the activity again in front of the class. The remaining seven activities were replaced with more communicative or game-based practice activities which involved students asking and answering questions about themselves. An example of a game-like activity was "Pass the ball" which Hoa used to practice asking and answering about ability (e.g. "What can you do? / I can..." and "Can you...? Yes, I can / No, I can't"). In this activity, music was played as the students passed a puppet around the class. When the music stopped, the student who held the puppet had to ask any peer a question. Although this activity involved some meaningful interaction in which students gave personally relevant answers, interaction was focused on reproducing the target structures and little negotiation of meaning was found.

In a more elaborate activity, teacher Nga showed the class four pictures of students in the school. She began by showing parts of the pictures on the screen and asked the students in pairs to use the target pattern to discuss whether the students partly hidden in the pictures were their friends or not. Some negotiation of meaning occurred as the students discussed their guesses. Next, the teacher showed the whole photo to the class so that students could check their guesses. This activity replaced the textbook activity in which students were required to ask and answer whether the textbook characters Mai, Nam, Phong and Quan are their friends or not using the target sentence structures are "Are they your friends? Yes, they are / No, they aren't". Observation notes reveal that the authentic photos engaged the students' interest. When Nga showed the photos on the screen and asked the class "Is this your friend?", many students shouted excitedly "Yes" and "No" in response. Nga then recast these responses to reflect the target form (i.e. "Yes, they are" and "No, they aren't") and asked the whole class to repeat the correct responses. This interaction followed an initiation-response-feedback (IRF) exchange pattern which emphasized accurately producing the target forms.

Nga expressed satisfaction with her students' performance, noting how they participated actively using English to work out whether the students in the pictures were their friends or not. She attributed this engagement to the meaningfulness of the activity which, as Nga believed, encouraged more effective communication. In the interview, Nga also further explained the reason why she replaced the production activity in the textbook with this guessing game. As she said: 
The production activity in the textbook cannot be used because it is not communicative. Students cannot give a meaningful answer by looking at the pictures of the characters in the book and ask whether they are their friends.

(Nga, speaking lesson 2)

Interestingly, the activity meets at least two of the four criteria for defining a task as proposed by Ellis (2018, p.12), namely, some kind of gap and a communicative outcome, although it does not meet the other two criteria of learners having to rely mainly on their own linguistic resources and, perhaps debatably, that their primary focus should be on meaning.

A similar commitment to enhancing communicative opportunities prompted the three Grade 4 teachers (Hoa, Nhu and Nam) to replace the production activities in the textbook with interview tasks. In these tasks, the students exchanged real information in pairs or groups and then selected pairs performed in front of the class. For example, Nhu gave each student a table to fill in with information about the names and the dates of birth of at least three students in the class. The students circulated around the class to interview their friends to fill out the form. Nhu then invited two volunteers to report the findings to the class. She made the following comment about this task:

When I organised the interview activity, my students had more opportunities to communicate with their peers and they did not have to focus their attention on the textbook.

(Nhu, speaking lesson 2)

On using a similar task, Nam commented:

In this activity, I want my students to decide who they want to ask. They can interact with more peers, not just the one next to them. Students can ask what they really want to know in English and their peers can give a true answer. This activity also excited my students a lot.

(Nam, speaking lesson 2)

Such table-completion information gap activities are archetypal PPP production activities. They also conform to the four criteria of a language learning task discussed earlier - a focus on meaning, a gap, learners rely on their own resources, and a communicative outcome (Ellis, 2018).

To sum up, the observation data showed that the teachers frequently adapted or replaced the production activities in the textbook so as to provide better opportunities for purposeful and meaningful practice. Most of these new or revised activities align better than the textbook activities with the definition of a 'task' in TBLT by virtue of more strongly emphasizing meaning, information gaps and communicative outcomes (Ellis, 2018). In talking about their lessons, the teachers expressed a shared commitment to enhancing communicative language use 
in the production phase but their views differed on the value of the presentation and practice phases. These divergent opinions were confirmed in the follow-up in-depth interviews which we discuss in the next section.

\subsection{Teachers' perceptions of the PPP approach}

The follow-up, in-depth interviews highlighted the conflicting views among the teachers of the PPP approach. Except Ly who tended to be somewhat neutral about this approach, the other six teachers were divided in their views of the PPP approach. Three of the teachers (Lan, Mai, Nhu) expressed positive views of this approach. They noted that the PPP sequence was suitable for lower level classes because it provided a predictable lesson structure. Furthermore, because they had learned to use this approach in their pre-service teacher education, they were familiar with it. As Nhu commented:

I have followed the PPP approach because I learned this approach from my preservice education and my colleagues. I find it effective for teaching speaking skills in that following this sequence, new target language items are drawn from contexts. Students learn how to communicate from the contexts. Repetitive practice is needed for the learning of new language items [...] only after a lot of repetition can students develop their fluency in the production phase.

Familiarity with the PPP approach made it easy not only for the teachers but also for their students. As Hoa commented:

The advantage when I followed those steps is students had been familiar with the steps, so the teaching was smoother. Students could approach the lessons more easily. However, I still feel that students' speaking and listening skills are not fully developed.

While noting this advantage, Hoa and two other teachers, Nam and Nga, spoke extensively about its limitations. They saw it is boring, mechanical and timeconsuming. As Nam commented:

I have noticed that some structural patterns in the presentation phase are quite long and if I follow all the required steps, I will have to spend a lot of time and my students will also get bored. Consequently, they will refuse to repeat the dialogue. The steps are "I ask them, they ask me"; then Group A asks group B; then closed pairs and open pairs. I feel this procedure is quite boring.

According to Nga, this issue was particularly problematic for her higher proficiency students who were easily bored by the lack of challenge of the lesson. As Nga commented: 
I have based my teaching on the three steps for a year and found it ineffective [...]. Some lessons were too easy, which bored the students. They even ignored my first step of presenting the language. They did not look at all.

This comment indicates that the activities suggested by the textbook material were often too easy for the more proficient learners. But it also implies a broader limitation of PPP, at least as practised in these classes, namely that the amount of controlled and repetitive practice in the first two phases is inherently demotivating, at least for more able students. Although six of the seven teachers tried to add communicative activities to the production phase, three of them commented that overall the PPP approach is ineffective because of its overemphasis on form practice rather than communicative use. As Hoa commented:

I think the steps are so fixed. It's like we arrange and assign things for students. We show them this is what they should say. Then students just have to follow the structural patterns we have taught them. This fails to enhance students' ability to use the language. I also think that here teachers play a more central role and just lead students to what they want them to do. [...] It is like the learning process is very theoretical. It means we have to provide students something in advance and they have to follow. We provide the theory for students before we get them to practice. I think this cannot enhance students' ability to use English language. It is like we force them to do what we want them to do, speak what we want them to speak.

As the observation data shows (see Table 2), the presentation and practice phases took a considerable amount of time, leaving limited time for the production phase. This concerned Hoa who was dissatisfied with the limited time allocated for communicative practice even though she was one of the three teachers who spent the most time on it. As she said:

The time allotted is not enough to maximize the communication ability in students. It is because the production phase just lasts around 10 to 15 minutes. I think it is quite short while this phase is very important. This is when students apply what they have learned in practice and expand their conversation beyond the structures they have just learned in the presentation and practice phases.

In the final part of the interviews, the researcher drew on Willis and Willis (2007) and Ellis (2003) to outline the principles of TBLT and to contrast TBLT with PPP. None of the teachers at this point were familiar with TBLT but all were interested in how it might work in practice. As Nam, whose students had lower proficiency that the other teachers, commented: 
I think it is better when students learned by doing or through activities. I think the students themselves can also learn better in this way than from what we have prepared for them.

Similarly, the description of TBLT prompted Nga (whose students were stronger than those of other Grade 4 teachers) to talk about her effort to reverse the sequence of PPP activities so that the production activity came first before any attention was given to the target structures. As Nga explained it:

Yes, I have learned a lesson from this, so I decided to reverse the steps if lessons were easy. I had students do the difficult part first [the production phase], and moved quickly through the other two parts. Then I provided them with the rules or something they need in the end. [...]. For example, as you can see in activity 3, I asked them to look at the pictures and encouraged them to say about the pictures. The aim was to see what had been known to them. Their performance helped me decide whether they were able to cover the lesson of the day. If it was enough, I got them to practice right after that.

This comment suggests that Nga was already intuitively oriented towards teaching with tasks even without awareness of TBLT.

\section{Discussion}

The first research question addressed the way the teachers implemented PPP. The results showed that the teachers frequently added interactive activities to the presentation phase and then carried out the drill-based dialogue practice and the structure explanation activities in the presentation phase. Four teachers (Nhu, Lan, Mai and Ly) expressed the belief that communication cannot be achieved unless the target vocabulary and structures have been explicitly provided and practiced. The views of these teachers corroborate DeKeyser's (2010) emphasis on establishing declarative knowledge before production practice. The other teachers (Nam, Hoa and Nga) also saw the importance of explicit, practiceoriented input but they disliked the time-consuming nature of the drill-based dialogue practice activity. They commented that this activity bored their students and provided little opportunity for communicative language use. These teachers doubted the steps they employed to implement the textbook presentation activity, even though they closely followed them. This tension between what teachers do and what they believe has been widely reported in teacher cognition research (Phipps \& Borg, 2009).

As with the presentation phase, all seven teachers followed a similar procedure in the practice phase in which they had students do mechanical, repetitive 
practice of the target vocabulary and structural patterns. Three teachers (Lan, Ly and Mai) insisted that without this practice, their students could not communicate freely and fluently in the production phase. These teachers strongly believed that communication only takes place when learners have been involved in sufficient repetitive practice of the target language items.

However, the other four teachers ( Nam, Hoa, Nga, and $\mathrm{Nhu}$ ) were concerned about the communicative value of the drill-based practice activity for this phase. Observation data supports their concern. It showed that this activity took a long time and failed to engage students. Also, while practice in this phase can play the important role of proceduralizing form-meaning mappings of grammatical and lexical patterns (DeKeyser, 2017), the observation data showed that the way this textbook practice activity was designed and implemented by all seven teachers was mechanical and failed to promote form-meaning connections (DeKeyser \& Cradio, 2013) and student engagement (Dörnyei, 2013). For children like those in this study, as Cameron (2001) suggests, game-like drills can be more effective.

Finally, most of the teachers adapted the production activities to make them more communicative and personal to the learners. They were strongly committed to developing their students' communicative abilities in the production phase and believed that no real language learning can be said to take place until students are able to use the language for themselves. Despite these strongly positive views and despite considerable variations across the lessons, the production phase was the shortest of the three phases - on average $21 \%$ of lesson time in the Grade 4 classes and $12 \%$ in Grade 3. An important question for PPP therefore is whether relegating communicative activities to the final phase in effect marginalises them.

In fact, previous studies (e.g. Choi \& Andon, 2014; V.G. Nguyen, 2014; V.G. Nguyen, Le \& Barnard, 2015) have reported that teachers often failed to carry out the production phase. For example, V.G. Nguyen, Le and Barnard (2015) showed that high school teachers in Vietnam "had little time, or apparently expertise to implement the third phase where students should use the target structures in freer production activities" (p. 8o). Similarly, H. M. Nguyen (2011) found that Vietnamese EFL primary teachers at a public school "emphasise [d] mastery of sentence patterns and words rather than stimulating creative or real-world communicative use of language" (p.240) and lacked the awareness, skills and resources to develop a more communicative pedagogy.

The second research question investigated the teachers' views of the PPP approach. Three teachers (Lan, Nhu and Mai) were positive about the PPP approach, and three (Nam, Nga and Hoa) were negative, with one, Ly, remaining neutral. The teachers who were positive attributed their satisfaction to their students' successful performance in the production phase. As confirmed in the observation data, most of their students were able to ask and answer using the tar- 
get patterns with ease in the production phase. While the considerable amount of structure explanation and practice of the target language items in the earlier phases may account for this, it is also probable that at least some of the students already knew how to produce the target structures and did not in fact need the explanation and practice.

But the other three teachers (Nam, Nga and Hoa) who expressed a negative view about PPP were not convinced that their students would consequently develop their ability to communicate. Despite providing their students with communicative and task-like activities in the production phase and observing them produce structurally accurate language, these teachers were concerned about the mechanical nature of PPP and cited teacher control and overreliance on target language items for free language production as constraining the learners' ability to genuinely communicate in English.

Observation data supported these teachers' concern. Although communicative activities were employed to engage students in meaningful language use (e.g. talk about themselves, their family and friends), the students were seen to treat these activities simply as a means of practicing the target forms. According to Willis and Willis (2007), when forms are taught prior to communicative practice, learners are likely to still be "in the mind-set that is concerned with producing specified forms" (p.209). Such overreliance on target language forms in the production phase may deny learners the opportunity to test their hypotheses about how language works (Swain, 1985), negotiate for meaning (Long, 2015), and engage in experiential learning (Evener, 2016; Nunan, 2011), all of which are claimed to promote language learning for young learners (Cameron, 2003; Pinter, 2017).

The findings from this study suggest two alternatives for moving forward. The first is to stay with PPP but to enrich the way it is delivered. One option is to replace the mechanical and repetitive practice activities in the first two phases with more meaningful and motivating activities. DeKeyser and Cradio (2013) argue that communicative drills are a more suitable type of practice for the practice phase because they emphasize content without neglecting attention to form. In the case of children, according to Cameron (2001) and Pinter (2017), drills can be made intrinsically motivating by turning them into play activities such as memory games, rhymes and songs. Another way to enrich PPP is to increase opportunities for communicative language use in the production phase. Our findings show that the teachers who allocated the least time to the production were those who believed most strongly that learners should not move to communicative activities until target forms had been thoroughly drilled. This finding has important implications for primary language teacher education - it suggests that a shift to a more communicatively-oriented curriculum needs to be supported by 
work with teachers in both pre-service and in-service programs on their beliefs and assumptions about the nature of communicative second language development in young learners.

This option of placing greater emphasis on the communicative phase of PPP overlaps with the second alternative - to adopt a task-based approach. The three teachers who were negative about PPP commented that a better way to help their young learners to learn English is through more stimulating activities than those provided in the PPP lessons. These teachers' perceptions, and in particular Nga's practice of introducing communicative activities in the first phase, suggest that this context might be fertile ground for raising teachers' awareness of TBLT, a point underscored by our finding that none of the participating teachers were aware of TBLT, despite their training and years of experience. In considering how TBLT might be introduced in this context, it is worth distinguishing between task-based and task-supported language teaching (TSLT). Task-based teaching eschews a role for explicit instruction prior to performance of a task and instead places emphasis on learning through task performance. On the other hand, TSLT as defined by Ellis (2018, p.126) consists of "a priori explicit instruction followed by the performance of a task", and as such corresponds closely to the PPP instructional sequence. This close correspondence with PPP makes TSLT a valuable option for increasing the salience of communicative tasks in PPP lessons without fundamentally restructuring the whole pedagogic approach. Littlewood (2007) has argued for such an approach in East Asian classrooms. Alternatively, for teachers such as Nga who have already transitioned towards a stronger version of TBLT, the principles of task-based teaching offer a powerful legitimation of their pedagogic instincts.

To conclude this discussion section, we acknowledge three limitations of the current study. First, although the study involved seven EFL teachers at six Vietnamese primary schools, only two lessons per Grade 4 teacher and one lesson per Grade 3 teacher were examined. Observing further lessons for each teacher would have provided a stronger basis for claims about these teachers' work. Second, despite measures taken to minimise the influence of being observed, the teachers may still have seen the researcher (a teacher trainer) as an expert and have adjusted the way they taught in the observed classes and the views they expressed in interviews accordingly. Third, as qualified implementers of the new curriculum, the participating teachers were strong in both pedagogical skills and language proficiency ( $\mathrm{B}_{2}$ and above), and as such were not selected to be representative of the wider population of primary school EFL teachers in Vietnam. 


\section{Conclusions}

This study investigated how the PPP approach has been implemented and perceived by seven primary school teachers in Vietnam. Based on the teachers' reported perceptions and analysis of their practices, we found that despite following similar procedures to implement the PPP speaking lessons, the teachers held divergent views about the efficacy of the PPP approach for teaching speaking skills. On the one hand, our findings suggest that the PPP approach can be successfully implemented in the Vietnamese primary school context, but requires some enhancements to the practice and production phases. On the other hand, we see fertile ground for fostering greater awareness and practice of TBLT as an alternative to PPP. We hope that the findings from the current study will provide useful insights for textbook writers, teacher trainers, and practitioners whose work is intended to enhance communicative abilities among EFL school learners. The findings are particularly important for primary English education in Vietnam where PPP has recently been adopted to develop communicative competence among primary school students, but where our classroom observation data suggest that it is failing to maximise learning opportunities and sufficiently motivate learners and learning.

\section{References}

Anderson, J. (2017). A potted history of PPP with the help of ELT journal. ELT Journal, 71(2), 218-227.

Anderson, L., \& Burns, R. (1989). Research in classrooms: The study of teachers, teaching, and instruction. Oxford: Pergamon Press.

Borg, S. (2006). Teacher cognition and language education. London: Continuum.

Butler, Y.G. (2015). English language education among young learners in East Asian: A review of current research (2004-2014). Language Teaching, 48(3), 303-342. https://doi.org/10.1017/So261444815000105

Byrne, D. (1986). Teaching oral English. Harlow: Longman.

Cameron, L. (2001). Teaching languages to young learners. Cambridge: Cambridge University Press. https://doi.org/10.1017/CBO9780511733109

Cameron, L. (2003). Challenges for ELT from the expansion in teaching children. ELT Journal, $57(2), 105-112$. https://doi.org/10.1093/elt/57.2.105

Carless, D. (2009). Revisiting the TBLT versus P-P-P debate: Voices from Hong Kong. Asian Journal of English Language Teaching, 19, 49-66.

Choi, T., \& Andon, N. (2014). Can a teacher certification scheme change ELT classroom practice? ELT Journal, 68(1), 12-21. https://doi.org/10.1093/elt/ccto59

Dang, T.C.T., \& Seals, C. (2018). An evaluation of primary English textbooks in Vietnam: A sociolinguistic perspective. TESOL Journal, 9(1), 93-113. https://doi.org/10.1002/tesj.309

DeKeyser, R. (Ed). (2007). Practice in second language: Perspective from applied linguistics and cognitive psychology. New York, NY: Cambridge University Press. https://doi.org/10.1017/CBO9780511667275 
DeKeyser, R. (2010). Practice for second language learning: Don't throw out the baby with the bath water. International journal of English studies, 10(1), 155-165. https://doi.org/10.6018/ijes/2010/1/114021

DeKeyser, R., \& Criado, R. (2013). Automatization, skill acquisition and practice in second language acquisition. In C.A. Chapelle (Ed). The encyclopaedia of applied linguistics (online) (pp. 1-8). Malden, MA: Wiley-Blackwell.

DeKeyser, R. (2017). Knowledge and skills in ISLA. In S. Loewen \& M. Sato, The Routledge handbook of instructed second language acquisition (pp.15-32). London: Routledge. https://doi.org/10.4324/9781315676968-2

Dörnyei, Z. (2007). Research methods in applied linguistics. Oxford: Oxford University Press.

Dörnyei, Z. (2013). Communicative language teaching in the twenty-first century: The 'principle communicative approach'. In J. Arnold \& T. Murphey (Eds.), Meaningful action: Earl Stevick's influence on language teaching (pp. 161-171). Cambridge: Cambridge University Press.

Ellis, R. (2003). Task-based language learning and teaching. Oxford: Oxford University Press.

Ellis, R. (2018). Reflections on task-based language teaching. Bristol: Multilingual Matters.

Ellis, R., \& Shintani, N. (2014). Exploring language pedagogy through second language acquisition research. London: Routledge.

Enever, J. (2016). Primary ELT: Issues and trends. In G. Hall (Ed.), The Routledge handbook of English language teaching (pp. 353-365). London: Routledge. https://doi.org/10.4324/9781315676203-30

García Mayo, M.P. (2018). Child task-based interaction in EFL settings: Research and challenges. International journal of English studies, 18(2), 119-143. https://doi.org/10.6018/ijes/2018/2/319731

Gass, S., \& Mackey, A. (2000). Stimulated recall methodology in second language research. Mahwah, NJ: Lawrence Erlbaum Associates.

Harmer, J. (2007). The practice of English language teaching. Harlow: Longman.

Hoang, V.V., Nguyen, T. Q., Phan, H., Do, H.N.T., Dao, L. N., \& Truong, M. N.T. (2015). Tieng Anh 3,4,5 (English 3, 4, 5) (3rd ed.). Ha Noi: Education Publishing House.

Labov, W. (1972). Some principles of linguistic methodology. Language in Society, 1(1), 97-120. https://doi.org/10.1017/So047404500006576

Littlewood, W. (2007). Communicative and task-based language teaching in East Asian classrooms. Language Teaching, 4o(3), 243-249. https://doi.org/10.1017/S0261444807004363

Long, M.H. (2015). Second language acquisition and task-based language teaching. Chichester: John Wiley \& Sons.

Merriam, S. B., \& Tisdell, E. J. (2016). Qualitative research: A guide to design and implementation (4th ed). San Francisco, CA: Jossey-Bass.

Nguyen, H.M.T. (2011). Primary English language education policy in Vietnam: Insights from implementation. Current Issues in Language Planning, 12(2), 225-249. https://doi.org/10.1080/14664208.2011.597048

Nguyen, V.G. (2014). Forms or meaning? Teachers' beliefs and practices regarding task-based language teaching: A Vietnamese case study. The Journal of Asia TEFL, 11(1), 1-36.

Nguyen, V.G., Le, C.V., \& Barnard, R. (2015). “Old wine in new bottles”: Two case studies of task-based language teaching in Vietnam. In M. Thomas \& H. Reinders (Eds.), Contemporary task-based language teaching in Asia (pp. 68-86). London: Bloomsbury.

Norris, J.M., \& Ortega, L. (2000). Effectiveness of L2 instruction: A research synthesis and quantitative meta-analysis. Language Learning, 50(3), 417-528. https://doi.org/10.1111/0023-8333.00136 
Nunan, D. (2011). Teaching English to young learners. Anaheim, CA: Anaheim University Press. Pinter, A. (2017). Teaching young language learners. Oxford: Oxford University Press.

Phipps, S., \& Borg, S. (2009). Exploring tensions between teachers' grammar teaching beliefs and practices. System, 37, 380-390. https://doi.org/10.1016/j.system.2009.03.002

Skehan, P. (1996). Second language acquisition research and task-based instruction. In J. Willis \& D. Willis (eds), Challenge and change in language teaching. Oxford: Heinemann.

Spada, N., \& Tomita, Y. (2010). Interactions between type of instruction and type of language feature: A meta-analysis. Language Learning, 6o(2), 263-308.

https://doi.org/10.1111/j.1467-9922.2010.00562.x

Stake, R.E. (1995). The art of case study research. Thousand Oaks, CA: Sage.

Swain, M. (1985). Communicative competence: Some roles of comprehensible input and comprehensible output in its development. In S. M. Gass \& C. G. Madden (Eds.), Input in second language acquisition (pp. 235-253). Rowley, MA: Newbury House.

Willis, D., \& Willis, J. (2007). Doing task-based language teaching. Oxford: Oxford University Press.

\section{Address for correspondence}

Trang Le Diem Bui

Faculty of Foreign Languages

An Giang University

Vietnam National University, Ho Chi Minh City

18 Ung Van Khiem, Đong Xuyen Ward

Long Xuyen city, An Giang province

Vietnam

bldtrang@agu.edu.vn

\section{Biographical notes}

Trang Le Diem Bui is a lecturer in the Faculty of Foreign Languages at An Giang University, Vietnam National University, Ho Chi Minh City. She has a Ph.D. in Applied Linguistics from Victoria University of Wellington, New Zealand, and over 15 years of teaching experience specializing in training pre-service and in-service EFL teachers. Her professional interests include language teacher education, task-based language teaching (TBLT), and content and language integrated learning (CLIL).

Jonathan Newton is an Associate Professor and Programme Director for the MA in TESOL/ Applied Linguistics at the School of Linguistics and Applied Language Studies (LALS), Victoria University of Wellington, New Zealand. He began his teaching career in China and has worked with teachers from across Asia for more than three decades. He has published five books and more than 70 book chapters and articles on teaching English as a second/foreign language. His scholarship spans task-based language teaching (TBLT), teaching listening and speaking, teaching vocabulary, and teaching for intercultural competence. 